\title{
Biblioteket som motor i å skape lokalsamfunn med sammenhengskraft $i$ en flerkulturell storbykontekst
}

\author{
Af Ragnar Audunson og Svanhild Aabø
}

\begin{abstract}
Er bibliotekfeltets nye ideer om bibliotekene som møteplasser i lokalsamfunnet og motorer for integrasjon og bygging av lokalsamfunn med sammenhengskraft $i$ samsvar eller $i$ konflikt med holdninger $i$ omgivelsene? Med utgangspunkt i ett case, en flerkulturell bydel i Oslo, søker artikkelen å avdekke hvordan interessentene $i$ et biblioteks lokalmiljø politikere, forvaltning, skoler, barnehager, frivillige organisasjoner og den alminnelige borger - ser på bibliotekets rolle som møteplass og lokalsamfunnsutvikler. Forskningsdesignet var sammensatt, med vekt på fokusgruppeintervjuer med nøkkelaktører $i$ lokalmiljøet samt representanter for beboerne, både bibliotekbrukere og ikke-brukere. Funnene viser at alle informantgruppene, inklusive beboere som nå ikke bruker lokalbiblioteket, hadde et sammensatt og variert syn på hvilken rolle biblioteket kan spille lokalsamfunnet, og forskjellene mellom dem var små. De la vekt på rollen som lavintensiv møteplass som fremmer samhørighet, som integrasjonsarena og flerkulturell møteplass og som stedsutvikler (placemaker) som kan bidra til a utvikle lokal identitet langt på vei i tråd med bibliotekfeltets ideer.
\end{abstract}

Ragnar Audunson, professor, dr. polit, Høgskolen i Osloog Akershus, (ragnar.audunson@hioa.no) Svanhild Aabø, professor, dr. polit, Høgskolen i Oslo og Akershus, (svanhild.aabo@hioa.no)

\section{Innledning og problemstilling}

Både folkebibliotekfeltets praktikere og bibliotekforskere har de siste årene vært opptatt av bibliotekets rolle som møteplass og dets rolle som en motor i utviklingen av lokalsamfunn med sammenhengskraft. Men dersom en endring og utvikling av bibliotekenes rolle skal slå igjennom og lykkes, er det ikke nok at den har legitimitet blant feltets egne aktører. Den må også ha legitimitet blant interessenter i omgivelsene - politikere, lokalforvaltning, organisasjoner og institusjoner i lokalmiljøet og den alminnelige borger. I denne artikkelen vil vi, med utgangspunkt i ett konkret case, fokusere på hvordan interessentene i et biblioteks lokalmiljø ser på bibliotekets rolle som møteplass og lokalsamfunnsutvikler. Våre forskningsspørsmål kan oppsummeres som følger:

1. Folkebibliotekforskere og bibliotekarer er opptatt av bibliotekets rolle som møteplass i den flerkulturelle storbyen og som en motor i utviklingen av lokalsamfunn med sammenhengskraft. Hvordan ser aktører i omgivelsene på dette? Ser de bibliotekets potensial på samme måte som de som tilhører det bibliotekfaglige praksisfeltet?

2. Hvordan mener aktørene i omgivelsene at biblioteket må utvikle seg dersom det skal spille en rolle som lokalsamfunnsutvikler?

Analysen baserer seg på data fra en casestudie i bydelen Alna i Oslo. 


\section{Tidligere forskning}

En forsker som var tidlig ute med hensyn til å studere politikeres bilder av folkebibliotek er Bob Usherwood. I boka Public Library Politics (Usherwood, 1993) rapporterer han fra en studie blant britiske lokalpolitikere. Usherwood fant blant annet klare forskjeller etter partipolitiske linjer. Lokalpolitikere fra Labour var i sterkere grad enn konservative politikere opptatt av biblioteket som et instrument for å fremme likhet og utjevne sosiale forskjeller.

Linley (1996) gjennomførte dels en litteraturstudie for å identifisere ulike aktørers syn på bibliotekets rolle i lokalsamfunnsutvikling, dels en empirisk intervjustudie i et mindre antall lokalsamfunn der respondentene dels var frivillige og ansatte som arbeidet med lokalsamfunnsutvikling, dels bibliotekansatte. I litteraturstudien fant hun en interessant forskjell mellom tekster produsert innenfor bibliotekfeltet og tekster produsert utenfor bibliotekfeltet, men av personer engasjert i lokalsamfunnsutvikling. Den siste gruppen var, i motsetning til lokalsamfunnsbibliotekarene, lite opptatt av bibliotekets rolle. Intervjuene med informanter fra ulike grupper i lokalsamfunnet, frivillige og administrativt ansatte i de to kommunene hun studerte empirisk, endret dette bildet noe. I intervjuene var det oftere henvisninger til bibliotekets potensial som møteplass i lokalsamfunnet og som et sted for informasjonsformidling og rådgivning.

Audunson undersøkte bibliotekarers, kommunepolitikeres og borgernes syn på bibliotekets rolle (Audunson, 2001). Et representativt, nasjonalt utvalg av den voksne befolkningen, et representativt utvalg kommunepolitikere samt alle fagutdannede bibliotekarer i norske folkebibliotek ble stilt samme spørsmål om den viktigste begrunnelsen for å bruke knappe, kommunale midler på folkebibliotek i stedet for til andre formål som eldreomsorg og skole. Respondentene kunne bare velge ett alternativ - det de så som den viktigste begrunnelsen for å bruke midler på det kommunale biblioteket. Gruppene tenkte ulikt. Politikerne var særlig opptatt av dannelse og formidling av en felles kanon: bibliotekene skal formidle den litteraturen som alle i landet bør kjenne til. Bibliotekarene var også opptatt av dette, men de var mer opptatt av bibliotekets rolle med hensyn til å fremme demokrati og likhet. Brukerne var mest opptatt av den instrumentelle nytten de har av biblioteket og av biblioteket som formidler av god fritidslesing. Svært få blant politikere, borgere og bibliotekarer pekte på bibliotekets rolle som møteplass i lokalsamfunnet som den viktigste grunnen til å bruke av knappe ressurser på biblioteket.

I en seinere undersøkelse blant medlemmer av det norske Stortingets Kirke- og undervisningskomite, som har ansvaret for bibliotekpolitikken, og sentrale byråkrater på feltet i departement og ABM-utvikling, ble bildet bekreftet (Audunson, 2005b). Politikerne var opptatt av bibliotekets rolle med hensyn til å fremme lesing og formidle den nasjonale kanonen. Flere ga uttrykk for at bibliotekarers tro på institusjonens betydning for demokratiet er utopisk. Her skiller stortingspolitikerne seg noe fra kommunepolitikerne. Til tross for at det også blant dem var dannelsesfunksjonen som ble sett på som viktigst, mente nesten hver fjerde kommunepolitiker at bibliotekets rolle i forhold til å fremme demokrati og bygge ned sosial ulikhet er den viktigste begrunnelsen for å bevilge knappe kommunale budsjettmidler til biblioteket. Men det som er særlig påfallende i de to undersøkelsene som omfatter norske politikere på kommunalt og nasjonalt nivå, er hvor få det er som snakker om bibliotekets rolle som møteplass. Bibliotekfeltet har jo de siste årene vært svært opptatt av nettopp det. Evjen (2012) mener imidlertid å kunne dokumentere en utvikling her. Mens en departementsutredning fra 1999-2000 om folkebibliotek knapt nevner møteplassfunksjonen med et ord, har denne rollen fătt bred plass i en tilsvarende utredning fra 2009 (St.meld. nr. 23 (2008-2009)).

Evjen \& Audunson (2009) gjennomførte fokusgruppeintervjuer med brukere og ikke- brukere i Oslo og Drammen i forbindelse med planer om nytt hovedbibliotek i de to byene. Et av deres hovedfunn var at både brukere og ikke-brukere hadde komplekse bilder av biblioteket: Det skal både være et litteraturens tempel og en dagligstue i byrommet med lav terskel; det skal samtidig være Sissel Kyrkjebø, Dumdum boys og Leif Ove Andsnes, som det ble sagt i en av fokusgruppene da medlemmene ble invitert til å beskrive biblioteket som en person.

Hedemark (2009) har i sin doktoravhandling analysert hvilke bibliotekbilder som kommer til uttrykk hos skribenter og debattanter som skriver i svenske aviser og ytrer seg på radio og TV om folkebibliotek. Hun konkluderer med at det er viktige dimen- 
sjoner ved bibliotekene, herunder deres rolle som møteplass, som i liten grad reflekteres i massemedia. Ettersom politikere må antas å påvirkes av måten mediene vinkler et tema, kan fraværet av slike viktige dimensjoner i den offentlige debatten få konsekvenser for politiske vurderinger. Kanskje er det et resultat av det vi ser i de to norske undersøkelsene som er referert over?

En studie fra Australia med respondenter fra de ulike forvaltningsnivåene - politikere så vel som administratorer og bibliotekledere - viste noen forskjeller mellom politikere på den ene siden og biblioteklederne på den andre som er interessante (Smith \& Usherwood, 2004). Blant lokalpolitikere var de bibliotekrollene som skåret høyest, bibliotekets rolle som formidler av informasjon og underholdning og dets rolle som et trygt lokalsamfunnssenter. Blant biblioteklederne på kommunalt nivå var det rollen som en institusjon som gir lik tilgang til informasjon, kunnskap og kultur som skåret høyest. Motstanden mot betaling for bibliotektjenester var sterk og uttalt i alle grupper av respondenter. Det var likeledes en entydig oppfatning blant politikere, administratorer og bibliotekarer på alle forvaltningsnivå at biblioteket kan ha en avgjørende betydning i sine lokalsamfunn.

Evjen (2012) studerte holdningene hos politikere i tre byer - Oslo, Aarhus og Birmingham - som alle planlegger eller er i ferd med å bygge nye hovedbibliotek. Hvordan legitimerer politikerne sin ressursbruk? Hva ser de som bibliotekets viktigste rolle i en storby? I hovedsak fant hun at politikerne ser bibliotekprosjektene i en byutviklingskontekst. Med hensyn til rolleoppfatning fant hun at politikernes holdninger i liten grad er i konflikt med det vi kan si er det etablerte norm- og verdigrunnlaget for folkebibliotekene.

Med hensyn til våre forskningsspørsmål - tenker omgivelsene annerledes enn bibliotekfeltet med hensyn til bibliotekenes rolle generelt og deres rolle som møteplass og motor i byutvikling spesielt - gir foreliggende forskning ikke entydige konklusjoner. Noe av den forskningen som er referert over indikerer at politikere, folk flest og bibliotekarer har ulike prioriteringer og at ikke minst politikerne vektlegger den tradisjonelle rollen knyttet til formidling av kvalitetslitteratur og den litterære kanon. Men det er også eksempler på forskning som indikerer at aktørene i omgivelsene har et komplekst bilde av biblioteket der dets rolle som møteplass inngår som et viktig element.

\section{Teoretiske perspektiv og grunnbegreper}

I PLACE-prosjektet der det prosjektet som det her rapporteres fra er et delprosjekt, er begrepsparet høyintensive versus lavintensive møteplasser sentralt. Dette begrepsparet er nærmere definert av Audunson (2005). Kort oppsummert innebærer høyintensive møter og møteplasser møter og steder der vi lever ut våre primære verdier og interesser, mens lavintensive møter og møteplasser beskriver møter og steder der vi eksponeres for andre verdier og interesser. Et lavintensivt møte innebærer at vi, uten selv å delta, observerer og må akseptere som legitimt aktiviteter som representerer utfoldelsen av interesser som er andre enn de vi selv står for. Den klassiske musikkelskeren må akseptere (men ikke sette pris på og like) at tungrock er en legitim interesse og verdi og vice versa, en som er aktiv i en kristen menighet eller humanetisk forbund eksponeres for og må akseptere som legitimt (men ikke nødvendigvis sette pris på og like) utfoldelsen av islamske verdier osv. Teorien om sosial kapital er opptatt av tillit - dels den tillit og den opplevelse av fellesskap som oppstår i tette grupper - høyintensive arenaer som for eksempel fellesskapet i en tett og nær vennekrets, en religiøs menighet, en supporterklubb for et fotballag, en profesjonsgruppe osv. - og dels den tillit i form av såkalt brokapital som eksisterer på tvers av slike tilhørigheter. En ateist, en muslim og en kristen står langt fra hverandre verdimessig. Men skal for eksempel en bydel der disse tre gruppene bor, fungere som er samfunn - et sted der mennesker finner sammen må det eksistere et minimum av tillit, for eksempel tillit til at de gruppene man selv ikke tilhører - "de andre" - ikke tar sikte på å okkupere samfunnet og bare tillate egen kultur å utfolde seg. Likeledes må det eksistere et minimum av fellesskap, for eksempel en opplevelse av å leve $\mathrm{i}$ et samfunn som inkluderer alle disse gruppene og som det er verdt å engasjere seg $\mathrm{i}$ - stemme ved valg og engasjere seg i noen felles aktiviteter for å gjøre lokalsamfunnet til et bedre sted å bo og leve $i$.

Å skape lavintensive møteplasser som kan generere dette minimum av felleskap er ikke trivielt $i$ en storbykontekst. Byer defineres gjerne som tette økologier av ukjente. Men man kan også argumentere for at byer er store og komplekse sosiale system der vi kan 
konstruere våre liv slik at vi bare utsettes for det som er kjent og som vi liker. Det er for eksempel rimelig å anta at sanginteressen er noenlunde likelig fordelt på tvers av livssyn. De fleste norske lokalsamfunn er for små til å holde seg med mer enn ett sangkor. I bassrekken til Lilleby blandede sangforening kan det godt tenkes at den sangglade sognepresten står side om side med den like sangglade lederen i humanetisk forbunds lokallag. I pausene på korøvelsene, på korseminarer og reiser mv. er det rimelig å anta at koret vil fungere som en lavintensiv møteplass der det bygges brokapital på tvers av religion og livssyn. Men flytter vår sangglade humanetiker til en storby som Oslo, kan han melde seg inn i Humanetisk forbunds kor og stå i en bassrekke der alle de andre deler hans livssyn. Han kan velge bosted, frekventere kafeer, velge nettsteder og radiokanaler mv. der han bare møter likesinnede. Den friheten til å velge som storbyen på denne måten åpner opp for, er på svært mange måter positiv. Men den skaper samtidig noen utfordringer med hensyn til å skape samfunn med sammenhengskraft.

Byrom planlegges og utformes gjerne med sikte på å skape "rene" lokalmiljø. Eksempler her kan være de nye bydelene som er under utvikling i Oslo - Bjørvika der den nye operaen ligger og der Deichmanske bibliotek skal få sitt nye hovedbibliotek og Tjuvholmen der Fearnley-Astrupmuseet for moderne kunst nylig åpnet. Utbyggingen her tar sikte på å fjerne det mangfoldet som tidligere preget disse områdene. Ta Bjørvika som eksempel. Fremdeles finner man rester fra den gangen dette var et viktig industriområde med skipsverft. Danskebåtene til København og Fredrikshavn har sitt anløpssted her. Når kulturfiffen rundt klokken 1800 eller 1900 er på vei til kveldens Wagnerforestilling, møter de dem med litt mindre kulturell kapital som skal med den såkalte "Dansebåten" til Fredrikshavn for å more seg og handle billig bacon. På gatehjørnene står øst-europeiske og nigerianske prostituerte som nå er kommet tilbake til tross for prostitusjonsforbudet. Om noen år vil dette være borte. Det vil være en ren bydel med opera, et signalbygg av et hovedbibliotek, kanskje det nye Munchmuseet, dyre boliger for den øvre del av middelklassen og såkalte barcodebygg for informasjons- og opplevelsessamfunnets dominerende bransjer innen media, IKT og konsulentvirksomhet.

Men det flerkulturelle samfunnet trenger rom der vi eksponeres for mangfoldet. Kan de lokale biblioteke- ne spille en rolle i så måte og bidra til en byutvikling som kan fremme sosial kapital av brotypen?

\section{Metode}

Vi gjennomførte en case studie i en multikulturell bydel i Oslo og valgte en sammensatt forskningsdesign. Bibliotekfilialen betjener en bydel som særkjennes ved å ha en svært høy andel innbyggere med innvandrerbakgrunn, om lag 45 prosent. Bydelen som ligger nordøst i Oslo, har lange arbeiderklassetradisjoner, og Trygve Lie som var FNs første generalsekretær, vokste opp her. Bydelen har svært høye prognoser for befolkningsvekst. Antall beboere er forventet å øke fra dagens 47000 til 65000 om ti år. Bydelen vil være et knutepunkt for kommunikasjon der det også er aktuelt å betjene mange som ikke bor i bydelen. Både den høye innvandrerandelen og den kraftige befolkningsveksten har konsekvenser for framtidas bibliotekbehov. Ikke minst er den kraftige befolkningsøkningen et selvstendig og sterkt argument for nye biblioteklokaler. Man kan ikke vente at en bydel med et innbyggertall som er noe høyere enn det man har i en større by som Drammen, skal kunne betjenes av et bibliotek på 870 kvadratmeter.

Bibliotekfilialen ligger i innbydende og nyoppussede lokaler som imidlertid er små. Filialen ligger i første etasje i et bygg som huser bydelsadministrasjonen, men lokalene har ikke vinduer der en utenfra kan se at det er et bibliotek som er plassert der. Filialen er godt forankret i bydelen med nære samarbeidsrelasjoner til bydelsadministrasjonen, skolene, barnehagene, frivillige organisasjoner mv. Tjenestene og arbeidsformene er godt tilpasset bydelens demografiske særtrekk. Bydelens minoritetsrådgivere har kontaktpunkt i biblioteket, man har lesesirkel for innvandrerkvinner, poesisamlinger rettet inn mot innvandrere, leksehjelpgrupper mv. Bydelen har en høyere aktivitet enn de fleste andre Deichmanfilialer med hensyn til besøk av skoleklasser og formidling til barn, og over 50 prosent av utlånet er barnemedier. Biblioteket brukes i stor grad som møteplass, noe som reflekteres i at antall besøk pr. innbygger er høyere enn antall utlån pr. innbygger.

Forskningsdesignen som ble valgt inkluderte en demografisk kartlegging av bydelens befolkningssammensetning og brukerstatistikk fra bibliotekfilialen. Nasjonale og internasjonale forbilder og modellprosjekter ble identifisert og studert, og det ble lagt vekt 
på erfaringer fra hovedbiblioteket og de andre bibliotekfilialene i Oslo i like stor grad som inspirasjon fra Idea Store-konseptet i London og andre relevante eksempler på innovative bibliotek. Det empiriske datasettet ble samlet fra flere kilder, som inkluderte a) erfarne bibliotekarer, b) nøkkelpersoner i den aktuelle bydelen og c) representanter fra lokalbefolkningen som omfattet både bibliotekbruker og ikke-brukere. Metoden for å samle inn de empiriske dataene omfattet workshops, fokusgruppeintervjuer og kvalitative individuelle intervjuer:

1. Det ble avholdt en workshop med ledere av bibliotekfilialer og andre avdelinger i hovedbiblioteket i Oslo. I tillegg ble lederne av tre filialer intervjuet individuelt.

2. Et fokusgruppeintervju med åtte nøkkelrepresentanter for bydelen ble avholdt, og kvalitative intervjuer med åtte andre sentrale aktører i omgivelsene ble gjennomført.

3. Fire fokusgruppeintervjuer med representanter for lokalbefolkningen ble avholdt, to med bibliotekbrukere og to med ikke-brukere av bibliotekfilialen.

4. Forskergruppa deltok på en workshop og et lokalt folkemøte som Plan- og bygningsetaten i Oslo arrangerte sammen med den aktuelle bydelsadministrasjonen. På workshopen deltok arkitekter, byplanleggere og andre sentrale aktører og ressurspersoner. Workshopen ble etterfulgt av et åpent møte for beboerne. Tema for møtet var det foreløpige planarbeidet for bydelens sentrumsutvikling. Vinnerteamet fra en arkitektkonkurranse presenterte utkastet til fornyelse av bydelssenteret.

Workshopene, fokusgruppeintervjuene og de individuelle kvalitative intervjuene ble gjennomført i løpet av høsten 2011 og januar 2012.

\section{Fokusgruppeintervjuene}

Vi valgte å vektlegge fokusgrupper fordi det er en metode som er godt egnet til å få fram hvordan folk tenker om et tema som ønskes kartlagt. Gjennom fokusgruppeintervjuer ønsket vi å få en dialog som bidro til å utvikle ideer om temaet og til å avdekke holdninger og kollektive meninger, og å gi et grunnlag for å danne et bilde av hvilken kontekst meningene dannes innenfor. Vi ønsket å få fram behov for og ønsker om den framtidige videreutviklingen av bibliotekfilialen i denne bydelen fra ulike målgrupper og befolkningssegmenter, samt å kartlegge nåværende svakheter i bibliotektilbudet. Oppslutningen om fokusgruppene var god, og samtalen i de ulike gruppene var livlig og utviklet seg i løpet av de par timene den varte, og alle deltakerne bidro aktivt.

Et mål for utvelgelse av informanter blant aktørene i omgivelsene var å identifisere og få $\mathrm{i}$ tale bibliotekets interessenter, i form av eksisterende og potensielle samarbeidspartnere. Noe av målet var å identifisere aktører som kan tenkes samlokalisert med biblioteket eller å være samarbeidspartnere på annen måte, samt å identifisere behov og ønsker hos faktiske og mulige brukere. Fokusgruppa med sentrale ressurspersoner i bydelen omfattet åtte deltakere som representerte ulike lag og foreninger i bydelen, som idrettslag, lokalhistorieforening og lokale kulturgrupper, ungdomsråd, internasjonalt råd og grupper for andre fritidsaktiviteter; ansatte i bydelsadministrasjonen og i barnehager, skoler, ungdomsklubber og skolebibliotek, samt i Plan- og bygningsetaten; og en bydelspolitiker som var leder i Oppvekst- og kulturkomiteen.

Fire fokusgrupper med representanter fra befolkningen $\mathrm{i}$ bydelen ble gjennomført. To av gruppene besto av bibliotekbrukere, den ene med deltakere $i$ aldersgruppa 18-39 år, den andre i aldergruppa over 40 år. De to andre fokusgruppene var sammensatt av ikkebrukere av det lokale biblioteket, inndelt i samme aldersgrupper. Utvalget ble trukket ut blant bydelens innbyggere. Det ble lagt vekt på å sette sammen fokusgruppene slik at vi fikk en sammensetning med hensyn til kulturell og etnisk bakgrunn, kjønn samt yrke og utdanning som er i tråd med bydelens befolkningssammensetning. Gruppene var ikke statistisk representative - man kan ikke generalisere fra gruppedeltakernes syn til alle innbyggere i bydelen. Derimot kan vi snakke om kategorirepresentativitet: Det er rimelig å anta at synspunktene som fokusgruppedeltakerne som helhet har, representerer viktige kategorier av synspunkter for de ulike gruppene som deltok i intervjuene. Totalt deltok 47 personer i de fire fokusgruppene med beboere.

\section{Individuelle intervjuer}

Det ble gjennomført individuelle intervjuer med sentrale aktører i bydelen som ikke hadde anledning til å delta i en fokusgruppe. Disse inkluderte en pakistansk minoritetsrådgiver i bydelsadministrasjonen, som også var aktiv med frivillig arbeid i immigrantmiljøet og i lokalsamfunnet for øvrig; et medlem av 
det lokale internasjonale rådet som bydelsadministrasjonen nedsetter, som tidligere hadde ledet bydelens ungdomsråd; et styremedlem i en lokal kulturgruppe, kalt "Kultur uten grenser"; rektor på den kommunale musikk- og kulturskolen og rektor for Oslo voksenopplæring; senterlederen ved bydelssenteret; en arkitekt fra firmaet som vant arkitekt- og byplankonkurransen om fornyelse av bydelssenteret; og avdelingssjefen for barn og unge i bydelsadministrasjonen.

\section{Funn}

Utgangssituasjonen: Samarbeid mellom ulike virksomheter $i$ bydelen og biblioteket

Biblioteket i Furuset er bydelens eneste folkebibliotekavdeling. Det ligger tett ved Furuset senter i 1. etasje i et bygg som også huser NAV og bydelsadministrasjonen. Plasseringen er dermed svært sentral i forhold til senteret, T-bane og bussholdeplass. Biblioteket er nylig pusset opp, ominnredet og det har fått nye møbler. Det har gitt biblioteket et løft, og det framstår som lyst og innbydende.

Biblioteket framstår imidlertid ikke som spesielt synlig. Lokalene er noe mindre enn det vi finner i Deichmanfilialer som dekker bydeler av tilsvarende størrelse

Biblioteket holder åpent fra kl.10-19 mandag og tirsdag, kl.10-16 onsdag, torsdag og fredag og fra kl.11-15 på lørdag. Det betyr at biblioteket på tre av seks åpningsdager i praksis ikke er tilgjengelig for de av bydelens innbyggere som er $i$ arbeid.

Det er åpenbart at biblioteket brukes aktivt av de nøkkelaktørene og institusjonene som var representert $\mathrm{i}$ intervjuene. Bydelen har hatt arrangement der, for eksempel et større arrangement i forbindelse med FN-dagen i 2010, og bydelens minoritetsrådgivere kan regelmessig treffes i biblioteket. Barnehagene drar på opplevelsesturer dit, og biblioteket plasserer bøker ut i barnehagene som både kan brukes der og lånes hjem av foreldrene. Ungdomsrådets leder understreket betydningen av biblioteket som et sted der barn og unge kan gjøre skolearbeid. De to skolebibliotekarene pekte likeledes på et utstrakt samarbeid. Eller som en av dem, Hilde fra et av skolebibliotekene, formulerte det: "...elevmassen bruker biblioteket utrolig mye. Utrolig positive tilbakemeldinger på skolen om biblioteket her. [...] Biblioteket her kommer på skolene og går i klassene og forteller om biblioteket. Bruker det til prosjekter, for å finne bøker og de får hjelp hvis det er noe spesielt. Fantastisk hyggelig å kunne ringe hit da. Så vi bruker det mye". Hildes utsagn er symptomatisk både for det tette samarbeidet med biblioteket som ble beskrevet og for den grunnleggende positive holdningen.

Befolkningens bruksmønster skiller seg fra det vi finner i avdelinger i Oslo vest (Majorstua og Røa) og gentrifiserte sentrumsbydeler som Grünerløkka og Torshov (Høimyr, 2009). Utlånsaktiviteten er lavere mens bruken av biblioteket til andre formål, for eksempel bruken av biblioteket som møteplass, relativt sett er høyere. Furuset hadde for eksempel i 2011 to utlån pr. innbygger, mens antall besøk pr. innbygger var tre. Deichmansystemet som helhet hadde dette året - som riktignok var et spesielt år på grunn av stengningen av Hovedbiblioteket etter 22. juli - 4,9 utlån og 3,7 besøk pr. innbygger. Furuset har altså et lavere utlån enn det som er gjennomsnittet for hele Deichman, men ligger ikke så langt unna gjennomsnittet når det gjelder antall besøk pr. innbygger. Det indikerer at biblioteket spiller en annen rolle for mange av brukerne enn i de avdelingene hvor de aller fleste besøk genererer et lån.

I 2011 hadde biblioteket på Furuset 86 klassebesøk med tilsammen drøyt 2000 elever. Her er aktiviteten ved avdelingen høyere enn på en gjennomsnittsfilial i Deichmansystemet. Denne satsingen har åpenbart gitt resultater, og utlånet til barn er stort: Nesten 55 prosent av det totale utlånet er barnemedier.

Kinoteket er et annet tilbud som særmerker Furuset filial. Bruken av dette i 2011 med til sammen 334 visninger og om lag 3100 besøkende viser at dette er et tilbud med et betydelig potensial. De begrensede åpningstidene på kveldstid gjør at det potensialet som Kinoteket kunne ha i forhold til yrkesaktive vanskelig kan realiseres.

Biblioteket har gjennomført en rekke tiltak som tar utgangspunkt i den store innvandrerandelen i bydelen, for eksempel:

- Leksehjelp

- Lesesirkel for innvandrerkvinner

- Poesikvelder for innbyggere med bakgrunn fra India og Pakistan 
- Bydelens minoritetsrådgivere har kontaktpunkt $\mathrm{i}$ bydelen.

Bibliotekets tette samarbeid med en rekke institusjoner og virksomheter i bydelen gjør at det framstår som godt forankret i lokalmiljøet. Men samtidig: det faktum at utlån pr. innbygger er markant lavere enn i Oslo som helhet samtidig som også antall besøk pr. innbygger er noe lavere enn byen ellers, peker i retning av at forankringen i befolkningen ikke er så sterk.

\section{Biblioteket som integrasjonsarena, møteplass og stedsutvikler}

Hovedinntrykket av intervjuene med så vel nøkkeaktører i bydelen som med representanter for de menige innbyggerne dokumenterer komplekse og varierte holdninger til hva et folkebibliotek er. At brukerne i fokusgruppene med menige innbyggere og nøkkelaktører fra institusjoner og virksomheter som samarbeider nært med biblioteket har et variert bilde av hva biblioteket kan være, er kan hende ikke så overraskende. Men det er interessant at vi finner nesten like komplekse bibliotekbilder også blant deltakerne i fokusgruppene for ikke-brukere. I fokusgruppeintervjuene for menige innbyggere ble deltakerne innledningsvis bedt om å assosiere fritt rundt hva de forbinder med institusjonen bibliotek og hva som er viktigst med biblioteket. I begge gruppene for ikkebrukere var assosiasjonene til hva biblioteket er og hva som er viktig med biblioteket mange. Stikkordmessig: Bøker og utlån av bøker, oppslagsverk, sitteplasser, et sted å roe helt ned, sosial møteplass, kompetansesenter for lokalbefolkningen, internasjonale aviser og medier, integrasjon, barneteater, datamaskiner, leksehjelp.

\section{Biblioteket som integrasjonsarena og flerkulturell møteplass}

Bibliotekets rolle som integrasjonsarena er noe bibliotekfeltet selv og bibliotekforskere er opptatt av bibliotekets potensial som arena for integrasjon (Atlestam \& Myhre, 2012; Audunson, Essamt \& Aabø, 2011). Er våre respondenter også oppmerksomme på denne mulige rollen?

Vi fant at bibliotekets rolle som integrasjonsarena ble understreket av flere i fokusgruppen med nøkkelaktører og i de kvalitative intervjuene med denne respondentgruppa. Bibliotekets rolle som en arena for språkutvikling og kunnskap om det norske sam- funnet, for eksempel gjennom lesing av bøker på norsk, ble framhevet. Flere pekte på dette som en av de viktigste funksjonene til biblioteket. Likeledes ble de pakistanske poesikveldene - Mushaira - som har blitt avholdt flere ganger på biblioteket, framhevet. Men det ble også formulert noen ønsker til ytterligere tiltak på dette feltet. Mariann fra barnehagesektoren skulle "ønske at både foreldretiltak og det her med norsk språkopplæring var en større del av biblioteket. Altså at man knyttet språkopplæring og integrasjon nærmere biblioteket". Poenget hennes er åpenbart at det vil gjøre det mulig å knytte læring sammen med opplevelse - en læringsstrategi som tar utgangspunkt i lystbetonte opplevelser. Den samme intervjupersonen understreket også at integrasjon ikke bare dreier seg om forholdet mellom innvandrere og etnisk norske, men også om forholdet mellom generasjoner. Biblioteket kan være et møteplass på tvers av ulike generasjoner nettopp fordi det brukes av barn, unge, voksne og eldre.

Minoritetsrådgiveren og rektor for en videregående skole som gir språkopplæring til innvandrere, la begge vekt på at man ikke bare må utvikle tiltak som retter seg inn mot særlige grupper - innvandrere, eldre, unge osv. - men også lage arrangementer som tar sikte på å samle på tvers av alder og etnisk og kulturell tilhørighet, for eksempel dikt- og poesikvelder som både omfatter norsk diktning og diktning fra innvandrerkulturer.

Flere av de som ble intervjuet pekte på at biblioteket er en møteplass som skaper et integrert lokalsamfunn preget av tillit og sosial kapital og der vold og kriminalitet forekommer i mindre grad enn uten en slik møteplass. "For meg er biblioteket et møtested for ulike kulturer. [...] Her kan folk lære om hverandres dikt, teater og slike ting. Jeg mener det er et veldig bra møtested. Man kan snakke litt, men lærer veldig mye av å sitte stille uten å si noe også. [...] Barn som bruker biblioteket og får kunnskap, begynner ikke med vold og kriminalitet" (Nisar, minoritetsrådgiver).

En respondent som representerte en barne- og ungdomsorganisasjon og den flerkulturelle foreningen Kultur uten grenser var opptatt av å anskueliggjøre - kanskje vi kan si sanseliggjøre - det kulturelle mangfoldet i bydelen gjennom for eksempel det han kaller kulturkister der man kan finne gjenstander som er typiske for ulike land og kulturer, og gjennom 
mat. Hans framtidsbibliotek er i stor grad et flerkulturelt opplevelsessenter. Slik knytter han an til biblioteket som opplevelsessenter i byrommet, som nå står sentralt i den faglige tenkningen omkring bibliotekenes rolle (Hvenegaard Rasmussen, Jochumsen \& Skot-Hansen, 2011).

Også brukerne og ikke-brukerne i fokusgruppene med representanter for bydelens menige innbyggere var oppmerksom på dette. Særlig interessant er det at også blant dem som ikke bruker biblioteket var oppmerksomheten omkring denne funksjonen høy. Innledningsvis i fokusgruppeintervjuene ble deltakerne bedt om å reflektere fritt omkring hva de forbinder med et bibliotek. I gruppa for ikke-brukere over 40 år var formuleringers om gikk igjen på dette spørsmålet for eksempel "et sosialt sted for å søke kunnskap om hverandre (vår uth.), "leksehjelp for barn", "internasjonalt tilbud" og "integrasjon" - alle disse kan sies å være knyttet til bibliotekets rolle som en arena for integrasjon. Da respondentene i fokusgruppene ble spurt om begrunnelser for at byen skal ressurser på biblioteket - ressurser som ellers kunne settes inn på andre områder med store behov som for eksempel eldreomsorg og barnehager - var likeledes referanser til bibliotekets potensial som arena for integrasjon hyppig tilbakevendende i alle de fire gruppene.

\section{Biblioteket som stedsutvikler (placemaker) og lokal identitetsbygger?}

Hva så med den mer overordnende rollen som stedsutvikler og motor for å bygge lokalsamfunn med sammenhengskraft?

Både i fokusgruppeintervjuet med nøkkelaktører og i de kvalitative intervjuene med representanter for denne respondentgruppa ble bibliotekets rolle og potensial som møteplass i bydelen understreket. Dette er en rolle biblioteket allerede spiller, i følge respondentene, men den kan utvikles og raffineres. Mariann fra barnehagene uttrykte at hun kunne tenke seg at "biblioteket kunne være et sånt hjerte $\mathrm{i}$ et byområde". Hun sammenlignet biblioteket med Norsk rikskringkasting før man segmenterte programtilbudet i kanaler for ungdom, for kulturinteresserte, for nyhetsnerder mv, det vil si en møteplass der man eksponeres for ulike kulturuttrykk og interesser, møter mennesker fra ulike generasjoner osv. Nettopp dette gjør biblioteket til en allmenndannende institusjon i lokalsamfunnet, framhevet hun. Andre framhevet at man har vært flink til å lage møteplasser for ulike grupper - for unge, for eldre, for idrettsinteresserte mv. - men at man nettopp trenger biblioteket som en møteplass for alle "som alle opplever som hyggelig og interessant. Der jeg møter vennene mine og jeg ser også noen mennesker jeg ellers ikke ville truffet. Den type møteplasser er veldig viktige. Kanskje viktigere enn andre steder i byen" (Halvor fra bydelsadministrasjonen). Skal vi framheve et punkt hvor det var enighet både i fokusgruppa og blant dem som ble intervjuet individuelt blant respondentene fra nøkkelaktørgruppa, blir det nettopp denne rollen som møteplass.

Hva skal skje på denne møteplassen? Hovedinntrykket er: Mer av det biblioteket allerede gjør. Man ønsker ikke et bibliotek som med hensyn til innhold og tjenester er helt annerledes enn dagens, men et bibliotek som tilbyr mer av de tjenestene det allerede har og gjør dem synligere og mer tilgjengelig. Ingen av nøkkelaktørenes forslag til tiltak går utover det folkebibliotekene i Oslo generelt og den aktuelle bydelen spesielt allerede gjør. Biblioteket skal fremdeles være et sted for litteratur og litteraturformidling og det skal bygge videre på tradisjonen som en arena for allmenndanning. Det skal videreføre tilbud som forfatterkvelder og foredrag, men bygge dem ut og systematisere dem og dermed framstå som den sentrale institusjonen i en lokal offentlig sfære - et lokalt litteraturhus. Biblioteket skal videreføre arbeidet det allerede driver med sikte på lesestimulering og språkutvikling generelt - $\mathrm{i}$ forhold til innvandrere spesielt, men systematisere og intensivere det ved at språkopplæring og integrering knyttes nærmere biblioteket (Mariann) eller ved etableres et ressurssenter for lese- og skriveopplæring i biblioteket (Vidar). Biblioteket er allerede et sted beboerne i stor grad bruker for å få informasjon om andre aktivitetstilbud og frivillige organisasjoner i bydelen, men det kan videreutvikles og systematiseres i form av et torg eller marked for utveksling av frivillige tjenester og informasjon om frivillige organisasjoner (Vidar).

Mange av forslagene fra nøkkelaktørene var knyttet til bygging av lokal identitet, for eksempel synliggjøre bydelens historie - FNs første generalsekretær Trygve Lie var født der - og synliggjøring av forfattere og kulturpersoner med tilknytning til bydelen, også forfattere og kulturpersonligheter med røtter i innvandrerkulturen. 
I fokusgruppene for brukere og ikke-brukere ble mange av de samme synspunktene og forslagene fremmet som dem vi fant blant nøkkelaktørene: Biblioteket bør ha kafe; det bør være et ressurssenter for alle typer kulturaktiviteter; det bør være litteraturkvelder der; det bør være et sted der man kan få oversikt over alle aktiviteter i lokalsamfunnet. Dette er eksempler på forslag som ble fremmet i fokusgruppene for brukere og ikke-brukere. Selv om alt dette er vanlige tilbud og tjenester i dagens bibliotek, kan det være at de ikke er synlige nok. For også i fokusgruppene for brukere - de som burde være best kjent med hva som faktisk skjer i biblioteket - ble det gitt uttrykk for at man savnet slike aktiviteter som går utover tradisjonell utlånsvirksomhet..

Samtidig ble det også i disse fokusgruppene for brukere og ikke-brukere framhevet at biblioteket må være gjenkjennelig. Det skal først og fremst være et bibliotek, men samtidig skal det være noe mer - et frirom i bydelen. Dette var en klar holdning også blant de yngste og de mest teknologiorienterte.

Jevnt over var det i fokusgruppene for brukere og ikke-brukere enighet om de forslagene som ble framsatt. Et forslag om at biblioteket bør holde oppe utover kvelden og dermed bidra til liv i bydelssenteret større deler av døgnet, skapte imidlertid debatt. Enkelte - riktignok et klart mindretall - var engstelige for at det vil tiltrekke seg ungdomsgjenger som vil skape bråk.

\section{Hvordan kan biblioteket bli en motor i lokalsamfunn- sutviklingen?}

Forholdet mellom syn på bibliotekets rolle, vår første problemstilling, og spørsmålet om hvordan biblioteket kan spille en rolle som lokalsamfunnsutvikler, vår andre problemstilling, kan være flytende. I dette avsnittet vil vi fokusere på funn knyttet til tiltak som har med tilgjengelighet å gjøre, bygningsmessige forhold samt organisasjon og samarbeid. Funnene går først og fremst $\mathrm{i}$ tre retninger og både nøkkelaktører og brukere og ikke-brukere framstår som svært samstemte.

$\varnothing k t$ tilgjengelighet er ett nøkkelord. Blant alle respondentgrupper ble det pekt på at bedre tilgjengelighet i form av økt åpningstid er en betingelse for at biblioteket skal bli et reelt og relevant tilbud, for eksempel for yrkesaktive og småbarnsforeldre i tidsklemma. De respondentene som representerte ungdom, var særlig opptatt av dette, først og fremst med utgangspunkt i sitt behov for et sted til lekser og skolearbeid. I bydelen er det mange barnerike innvandrerfamilier der det er vanskelig å finne ro til skolearbeidet hjemme. Denne gruppa gikk også inn for søndagsåpent og mente at det vil øke bruken av biblioteket vesentlig.

Det andre virkemiddelet som alle respondentgrupper pekte på, var samarbeid med andre institusjoner og virksomheter i bydelen. Her var spennvidden stor fra Natteravnene ${ }^{1}$ via NAV ${ }^{2}$ til barnehage og skole (kanskje det som hyppigst ble nevnt) til kulturaktiviteter som musikk, kino, korsang mv.

Det tredje virkemiddelet er knyttet til bibliotekslokalene. I fokusgruppene for brukere og ikke brukere var man opptatt av at dagens lokaler er for små. Det biblioteket man ser for seg som en motor i lokalsamfunnsutviklingen, må gi rom for at et stort spekter av ulike aktiviteter og bruksmåter kan foregå parallelt. Det ble også pekt på at dagens lokaler er for lite. Samtidig var man opptatt av at dagens sentrale beliggenhet umiddelbar tilknytning til kollektivtransport i kjøpesenter må beholdes. Det ble likeledes pekt på at dagens bibliotek er for lite synlig. Man kan for eksempel ikke se inn i det fra gateplanet og se at her er det et bibliotek. Det bør man kunne, ble det hevdet.

Nøkkelaktørene delte disse synspunktene, men la mer eksplisitt vekt på behovet for et sentralt plassert nybygg som både kan være et landemerke i bydelen og som kan gi rom for det samarbeidet med andre virksomheter som er beskrevet foran. To utsagn fra nøkkelinformantene kan illustrere dette:

"Et felles hus hadde vært lurt. Et åpent kulturhus der biblioteket er en del. At man ikke skiller så mye mellom bibliotek og andre tilbud. Si at du hadde et sånt felles kulturhus med en felles kafé, et felles rom der man kommer inn for så å kunne velge hvor du vil gå etter interesser. Om du vil gå på dans en plass, om du vil sitte og snakke med voksne en plass, lese eller ha leksehjelp. Et flerbrukshus, der skillene ikke er så store, men der hvor man har alle tilbudene" (Ellen, avdelingsleder for barn og unge i bydelsadministrasjonen).

"Men hvis det skal bygges noe nytt og stort og fint, så ønsker jeg meg et kulturhus hvor biblioteket kan være en del av det. Det er det vel flere andre som 
har vært inne på også. For eksempel med øvingslokaler for forskjellige kulturelle aktiviteter. Det er et behov for det i området vårt" (Arvid, politiker fra bydelsutvalget).

Mariann fra barnehagene problematiserte imidlertid kulturhusperspektivet. Hun la vekt på viktigheten av at biblioteket er der hvor folk ferdes og oppholder til daglig og hun følte seg ikke sikker på at et kulturhus er et slikt sted.

Oppsummeringsvis identifiserte vi tre modeller med hensyn til samarbeidsløsninger og lokaler:

1. Kulturhusmodellen, der biblioteket lokaliseres sammen med kino, lokaler for ulike kulturelle aktiviteter, kulturskole mv.

2. Samvirkemodellen, der biblioteket lokaliseres sammen med andre offentlige tjenesteytere, for eksempel det lokale NAV-kontoret som har ansvar for sosial- og trygdeytelser, arbeidsformidling mv.

3. Idea Store-modellen: et frittstående bibliotekbygg som fungerer som et signalbygg $\mathrm{i}$ bydelen og der bibliotek og livslang læring kobles sammen i én institusjon.

\section{Konklusjoner og videre forskning}

Hva forteller funnene om våre problemstillinger? Vår overordnede problemstilling og vårt første forskningsspørsmål var: Er bibliotekfeltets nye ideer om bibliotekene som møteplasser i lokalsamfunnet og motorer for integrasjon og bygging av lokalsamfunn med gjennomslagskraft i samsvar eller i konflikt med holdninger i omgivelsene?

Forholdet mellom et profesjonsfelt og omgivelsene med hensyn til endringer kan gå i tre retninger: Profesjonsfeltet kan foreslå endringer som omgivelsene ikke aksepterer fordi de er for radikale og bryter med forventningene til hva den aktuelle institusjonstypen skal være. Mange forslag om liberaliseringer i kriminalomsorgen er blitt stoppet av den grunn; de bryter med omgivelsenes bilder av hva straff og fengsel skal være. I andre tilfelle mener omgivelsene at endringene kommer for sent og er for små. Til tross for at for eksempel Den norske kirke de siste 50 årene har gått igjennom en veritabel revolusjon når det gjelder synet på seksualitet og kjønn, er det en utbredt oppfatning i omgivelsene at det er for lite og for sent. - Holder de nå ennå på med dette homofilimaset sitt, mener mange. Det tredje utfallet er den lykkelige situasjonen at det er samsvar mellom profesjonsfeltets reformforslag og omgivelsenes holdninger.

Hovedinntrykket er at ideene om bibliotekfeltets ideer om biblioteket som møteplass og som arena for lokalsamfunnsutvikling og integrasjon ikke er på kollisjonskurs med de tankene våre informanter har om bibliotekets rolle i lokalmiljøet. I begge informantgruppene - nøkkelaktørene og de menige innbyggerne - fant vi en høy grad av bevissthet om bibliotekets rolle som møteplass med potensial til å utvikle et lokalsamfunn med sammenhengskraft. Da for eksempel brukere og ikke-brukere i fokusgruppene for menige innbyggere ble spurt om hva som kan forsvare at knappe offentlige midler som kunne vært brukt på andre gode formål brukes på det lokale biblioteket, var ikke kommentarene og begrunnelsene først og fremst knyttet til den individuelle nytten bydelens borgere har av biblioteket, men til bydelens behov for en samlende møteplass. Det er interessant at også fokusgruppene for ikke-brukere la vekt på slike forhold. I fokusgruppeintervjuet og de individuelle intervjuene med nøkkelaktører gikk formuleringen som vektla biblioteket som et hjerte i bydelen, som en brobygger og et bindeledd mellom ulike institusjoner og et møtested for ulike kulturer igjen.

Konklusjonen fra denne case studien på vårt første forskningsspørsmål synes å være at aktørgruppene i omgivelsene langt på vei ser bibliotekets potensial som møteplass i sin flerkulturelle bydel og som en motor i utviklingen av et lokalsamfunn med sammenhengskraft på samme måte som det bibliotekfaglige praksisfeltet. Hos alle de tre gruppene som våre informanter besto $\mathrm{av}$ - interessenter, brukere og ikke-brukere av lokalbiblioteket - var oppmerksomheten om biblioteket som møteplass sterk, og bibliotekets betydning som en arena for integrasjon ble framhevet. Forskjellene mellom de tre gruppenes syn synes heller ikke store. At også ikke-brukerne ga uttrykk for et variert og komplekst bilde av biblioteket, kan synes overraskende. Det kom imidlertid fram i fokusgruppene at flere av dem hadde brukt lokalbiblioteket tidligere, mens andre brukte andre bibliotek. Konklusjonen antyder at bibliotekarer som søker å utvikle biblioteket som en møteplass som kan bidra til identitet, sammenhengskraft og brokapital i lokalsamfunnet, ikke trenger å bekymre seg for at de 
løper foran holdningene til innbyggere og interessenter ellers.

Med hensyn til vårt andre forskningsspørsmål - hvordan kan bibliotekets rolle som lokalsamfunnsutvikler realiseres - er respondentgruppene samstemte og peker på tre forhold:

Bedre tilgjengelighet $\mathrm{i}$ form av utvidete åpningstider. Bredt samarbeid med institusjoner og virksomheter i bydelen - offentlige så vel som frivillige Lokaler som er synlige, som åpner opp for et variert spekter av aktiviteter og som kan bidra til å synliggjøre bydelens historie.

Et særtrekk ved bydelen som vi har studert i dette case, er at den er med i et sentralt "Områdeløft" der bydelsadministrasjonen samarbeider nært med den norske Husbanken for å bedre livskvaliteten for beboerne i området, blant annet gjennom å skape arenaer for møteplasser i lokalsamfunnet. Sentrale byråkrater var orientert om bibliotekforskning og moderne bibliotekutvikling, som for eksempel Idea Stores i London, og de tok initiativ til denne studien. $\AA$ ha et så aktivt forhold til bibliotekets potensiale som lokalsamfunnsbygger er kanskje ikke representativt for bydelsadministrasjoner generelt. Det er likevel interessant at representantene for beboerne, som ikke kan forventes å ha spesiell innsikt i bibliotekforskning eller moderne bibliotekutvikling, ga uttrykk for syn som gikk i samme retning. Det kan være behov for mer forskning, for eksempel i en annen innvandrerbydel, for å se om våre konklusjoner er robuste.

\section{Noter}

1. Natteravnene er en frivillig virksomhet der voksne rekrutteres for å være ut i nærmiljøet på kveldsog nattetid for å forhindre bråk blant ungdomn

2. NAV er en nyopprettet institusjon som integrerer tre tidligere selvstendige etater på statlig og kommunalt nivå: Trygdeetaten (tidligere statlig), sosialkontorene (tidligere kommunale) og arbeidskontorene (tidligere statlige).

\section{Referencer}

Aabø, S \& Audunson, R (2012). Use of library space and the library as place. Library \& Information Science Research 34(2), 138-149.

Aabø, S, Audunson, R, \& Vårheim, A (2010). How do public libraries function as meeting places? $\mathrm{Li}$ brary \& Information Science Research 32(1), 16-26.

Atlestam, I \& Myhre, R (Red.) (2012). Det mångspråkiga biblioteket - en nödvendig utopi. Lund: BTJ Förlag.

Audunson, RA (2001). Folkebibliotekenes rolle i en digital framtid: Publikums, politikernes og bibliotekarenes bilder. I: Det siviliserte informansjonssamfunn: Folkebibliotekenes rolle ved inngangen til en digital tid, 206-224. (R.A. Audunson \& Winfeld Lund, N., red.).

Audunson, RA (2005a). The public library as a meeting-place in a multicultural and digital context: The necessity of low-intensive meeting-places. Journal of Documentation, 61(3), 429-441.

Audunson, RA (2005b). How do politicians and central decision-makers view public libraries? The case of Norway. IFLA Journal 31(2), 174-182.

Audunson, R, Essmat, S \& Aabø, S (2011). Public libraries: A meeting place for immigrant women? Library \& Information Science Research 33(3), 220227.

Evjen, S (2012). Placing the public library - comparative analysis of political perceptions. København: Det Informationsvidenskabelige Akademi. (PhD-avhandling).

Evjen, S \& Audunson, R (2009). The complex library: Do the public's attitudes represent a barrier to institutional change in public libraries? New Library World 110(3-4), 161-174.

Fisher, KE, Saxton, ML, Edwards, PM, \& Mai, J-E (2007). Seattle Public Library as place: Reconceptualizing space, community, and information at the central library. In J. Buschman \& G. J. Leckie (Eds.), The library as place: History, community, and culture (pp. 135-160). Westport, CT: Libraries Unlimited. 
Hedemark, Å (2009). Det föreställda folkbiblioteket: en diskursanalytisk studie av biblioteksdebatten i svenska medier 1970-2006. Uppsala: Uppsala universitet. (Avhandling (doktorgrad)).

Hvenegaard Rasmussen, C, Jochumsen, H \& SkotHansen, D (2011). Biblioteket i byudviklingen : oplevelse, kreativitet og innovation. København : Danmarks Biblioteksforening.

Høimyr, T (2009). Sosial kapital på biblioteket? : en undersøkelse av bruken av to lokalbibliotek i Oslo.

Oslo: Høgskolen i Oslo. (Masteroppgave i bibliotekog informasjonsvitenskap). https://oda.hio.no/jspui/ handle/10642/322

Japzon, AC \& Gong, H (2005). A neighborhood analysis of public library use in New York City. Library Quarterly 75(4), 446-463.

Johnson, CA (2012). How do public libraries create social capital? An analysis of interactions between library staff and patrons. Library \& Information Science Research 34(1), 52-62.

Kretzman, J, \& Rans, S (2005). The engaged library: Chicago stories of community building. Evanston,
Ill.: Northwestern University. Retrieved from http:// www.abcdinstitute.org/docs/ULCReport.pdf.

Leckie, GJ, \& Hopkins, J (2002). The public place of central libraries: Findings from Toronto and Vancouver. Library Quarterly, 72(3), 326-372.

Linley, R (1996). The Role of the Branch Library in Community Development and Community Regeneration. Sheffield: University of Sheffield, Department of Information Studies.

Smith, K \& Usherwood, B (2004). Political perceptions of the public library: The Australian view. Paper presented at ALIA 2004. Retrieved from http:// http://conferences.alia.org.au/alia2004/pdfs/ smith.k.paper.pdf

St.meld. nr, 23 (2008-2009)). Kunnskapsallmenning, møtestad og kulturarena i ei digital tid. Oslo: Kulturog kyrkjedepartementet.

Usherwood, B (1993). Public Library Politics - The role of the elected member. London: Library Associations Publishing. 